\title{
HEMATOLOGICAL AND BIOCHEMICAL EFFECTS OF CURCUMIN IN SCHISTOSOMA MANSONI INFESTED MICE
}

\author{
ESSAM A. MAHMOUD* ${ }^{*}$ and ASHRAF A. ELBESSOUMY** \\ * Clinical Pathology Department, Faculty of Veterinary Medicine, Zagazig University \\ ** Biochemistry Department, Faculty of Science, Alexandria University \\ E-mail: E-mail: essammahmoud97@yahoo.com
}

\section{ABSTRACT}

Received at: $22 / 6 / 2014$

Accepted: 10/9/2014
In order to investigate the effect of curcumin on treatment of Schistosoma mansoni infested mice. Forty, male CD-1 Swiss albino mice used in this experiment, divided equally into 4 groups, the first kept as control, the second supplemented with curcumin, the third infected with S.mansoni and the $4^{\text {th }}$ infected then treated with curcumin. The results emphasized on the presence of anemia leucopenia, neutropenia and esinophilia in infested groups either treated or not with somewhat an improvement in the treated group. The biochemical parameters showed that curcumin tries to restore the increased transaminases, alkaline phosphatase, antioxidants, triglycerides and low density lipoproteins to normal. Finally, curcumin treated group still closer to the infected group more than to the normal control group.

Keywords: Schistosoma, Curcumin, Hematology, Leucocytosis, Biochemical, Antioxidants.

\section{INTRODUCTION}

There is no doubt that schistosomiasis is one of the major communicable diseases which affecting human and animals either domestic or wild, as it comes secondly to the malaria with socio-economic and health importance in the developing world (Bergquist and Colley 1998). Schistosomiasis is a chronic debilitating parasitic disease in tropical and subtropical countries caused by Schistosoma species (Gryseels et al., 2006). It is affecting about 200 million people infected worldwide and almost 600 million at risk.

Schistosoma is still one of the most prevalent epidemic disease in Egypt and in other developing countries in spite of many attempts to control this parasitic infection over many years (El-Khoby et al., 2000). Schistosomiasis mostly affecting the liver and intestine causing granuloma formation, fibrosis and certain necrotic changes in the hepatic tissues (Elbanhawey et al., 2007).

Current treatment relies on praziquantel (PZQ) (Zhang and Coultas 2013). However, praziquantel does not treat early infection or prevent reinfection (Magnussen, 2003). In addition to, numerous evidences indicates to increasing the emergence of strains of Schistosoma mansoni resistant to praziquantel (Melman et al., 2009, Van der Werf, 2003 and Zhang and Coultas 2013).
In the last few years, there is an obvious increase in searching for antiparasitic drugs from natural sources, especially from plants, which are the main source of biologically active compounds for the development of new treatments (Magalhães et al., 2009 and Silva et al., 2009). One of these compounds is curcumin.

Curcumin is a yellow pigment from rhizomatous plant turmeric (Curcuma longa) widely cultivated in tropical and subtropical regions throughout the world, (Cerny et al., 2011). Extensive in vitro and in vivo studies have indicated that curcumin has a potent antitumor, anti-viral, anti-oxidant, and antiinflammatory properties (Aggarwal and Harikumar, 2009 and Tu et al., 2011). Moreover, several recent reports showed that curcumin exerts beneficial effects in animal models of liver toxicity, inflammation and cirrhosis (Chen and Zheng, 2008 and Fu et al., 2008).

Several reports revealed that curcumin enhances the hepatic detoxification by acting as a free radical scavenger, increases the glutathione/glutathione disulfide ratio to reduce oxidative stress and inhibits the activation and nuclear translocation of nuclear factor kappa-light-chain-enhancer of activated B cells

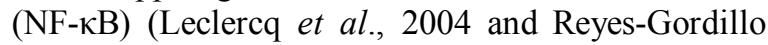
et al., 2007). Recent study postulated that curcumin protects against hepatic fibrosis by inactivating hematopoietic stem cells (HSCs) through activation of peroxisome proliferator-activated $\gamma$ - receptor, which interrupts platelet-derived growth factor and epidermal growth factor signaling in activated HSCs (Lin and Chen, 2008). 
The first studies about the curcumin effects on Schistosoma mansoni showed the schistosomicidal effect of the oil extract of C. longa against S.mansoni infected mice (El-Ansary et al., 2007). Morias et al. (2013) and Allam (2009) described in vitro and in vivo Schistosomicidal activity of curcumin against $S$. mansoni adult worms. Recently, El-Agamy et al. (2011) showed that curcumin has a potent antifibrotic activity in suppressing and reversing S. mansoni-induced liver fibrosis.

On the basis of anti-protozoal and anti-parasitic activity of medicinal plants and natural products, the aim of the present work was to evaluate the antishistosomal activity of curcumin against Shistosoma mansoni.

\section{MATERIALS and METHODS}

\section{Chemicals:}

All common chemicals used were purchased from one of the following suppliers Sigma Co. (St. Loius, MO, USA). All other chemicals and reagents were of the highest purity commercially available and were purchased from the British Drug Houses (BHD), Poole Dorset, UK. The diagnostic kits are purchased from Human Company (Germany).

\section{Experimental animals:}

Twenty healthy and other Twenty infected (with eighty Schistoma mansoni cercaria) male CD-1 Swiss albino mice (8-10 weeks of age) were used throughout the present study and were purchased from Theodore Bilharz Research Institute (TBRI, Imbaba, Giza, Egypt). All animals were maintained on standard commercial diet and water ad libitum.

\section{Experimental design:}

Animals were divided into four groups with 10 mice in each group, as the following:

Group I: healthy control group received normal diet (non-infected non-treated).

Group II: healthy received normal diet mixed with curcumin $(300 \mathrm{mg} / \mathrm{kg} /$ day) (non- infected treated) from the $15^{\text {th }}$ day after receiving the animals and continue for 4 weeks.

Group III: infected and received normal diet (infected non-treated).

Group IV: infected and received normal diet mixed with curcumin $(300 \mathrm{~g} / \mathrm{kg} /$ day) (infected treated) from the $15^{\text {th }}$ day after receiving the animals and continue for 4 weeks.

Five animals from each group were sacrificed for sampling at the $2^{\text {nd }}$ and $4^{\text {th }}$ week post treatment.

\section{Hematological examination:}

Whole blood samples were collected from retroorbital venous plexus of mice in a clean EDTA tube for determination of erythrocytic count (RBCs), hemoglobin concentration $(\mathrm{Hb})$, haematocrit value (PCV), total and differential leucocytic count according to Feldman et al. (2000).

\section{Biochemical Analysis:}

Serum and liver homogenate were taken for all measurements. Serum samples were collected and stored at $-20^{\circ} \mathrm{C}$ until used. The liver was dissected out, washed in ice-cold saline, blotted dry, and weighed. Then homogenate was prepared in phosphate buffer $0.1 \mathrm{M}, \mathrm{pH} 7.4$ and used for the biochemical analysis.

\section{Serum hepatic enzymes:}

Activities of serum Aspartate transaminase (AST) and Alanine transaminase (ALT) were assessed according to Reitmans and Frankel (1957). alkaline phosphatase (ALP) was assayed by the kinetic methods of human kits (Germany) according to EDKC (1972). Total protein and albumin were measured according to Doumas et al. (1981). Serum globulin was calculated by subtracting the obtained albumin value from the total protein as described by Doumas and Biggs (1972). Tumor necrosis factor-alfa (TNF-a) and Alfa- fetoprotein was assayed using a commercial ELISA kit.

\section{Estimation of serum lipids:}

Total cholesterol (TC) measured according to (Richmond 1973), Triglycerides (TG), according to Wahlefeld and Bergmeyer (1974) and HDL-C was estimated according to Warnik et al. (1983) by the human kits (Germany). LDL- C were estimated by the formula of, Friedewald et al. (1972).

LDL- $\mathrm{C}=($ total cholesterol $)-($ HDL-C $)-$ (triglycerides/5)

\section{Determination of non-enzymatic antioxidants}

Reduced GSH was determined according to the method of Ellman (1959) based on the formation of a yellow coloured complex with Ellman's reagent $(0.0198 \%$ DTNB in $1 \%$ sodium citrate). The color developed was read at $412 \mathrm{~nm}$.

\section{Assay of antioxidants enzymes:}

Superoxide dismutase was assayed spectrophotometrically according to Paoletti and Mocali (1990). This method consists of purely chemical reaction sequence that generates superoxide from molecular oxygen in the presence of EDTA, manganese (II) chloride and mercaptoethanol. NAD $\mathrm{H}$ oxidation is linked to the availability of superoxide anions in the medium. The decrease in absorbance at $340 \mathrm{~nm}$ was monitored for $20 \mathrm{~min}$ at $5 \mathrm{~min}$, One unit of SOD activity is defined as the amount of enzyme required to inhibit the rate of NADPH oxidation of 
the control by $50 \%$. Catalase assay was carried out according to the method of Aebi (1974). One unit was defined as that amount of the enzyme which converts 1 mole substrate to product in $1 \mathrm{sec}$.

\section{Statistical analysis:}

Results were expressed as mean \pm standard error (S.E.). One-way analysis of variance (ANOVA) test by SPSS 16.0 for windows was carried out to test for any differences between the mean values of all groups. A value of $p<0.05$ was interpreted as statistically significant Tamhane and Dunlop (2000). Means at the same row followed by different letters were significantly different and the highest value was represented with the letter (a).

\section{RESULTS}

The erythrogram, in the present work, showed microcytic hypochromic anemia in groups (III \& IV) all over the experimental periods (Table 1). Group (II) showed an insignificant change in RBC count as compared to control group. Both of groups (III \& IV) showed leucopenia as compared to control group although supplementation of curcumin to noninfected mice improved the WBCs count compared to control group (Table 2). On regarding the differential leucocytic count, our results revealed neutropenia, lymphopenia and eosinophilia in groups (III \& IV) when compared with control group (Table 2). Supplementation of curcumin to group (II) insignificantly increased neutrophil, esinophil and lymphocytic count as compared to control group.

Table 1: Erythrogram in mice infested with $S$. mansoni and or treated by curcumin (mean \pm .E).

Data are presented as mean $\pm \mathrm{SE}, \mathrm{n}=5$ and values which have different letters are significantly differs from each other at $\mathrm{p} \leq 0.05$ using ANOVA test.

\begin{tabular}{|c|c|c|c|c|c|}
\hline & Groups & \multirow[t]{2}{*}{$\mathbf{I}$} & \multirow[t]{2}{*}{ II } & \multirow[t]{2}{*}{ III } & \multirow[t]{2}{*}{ IV } \\
\hline & Parameters & & & & \\
\hline \multirow{6}{*}{ 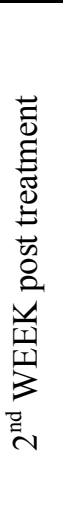 } & $\operatorname{RBCS}\left(\mathrm{X} 10^{6} / \mathrm{UL}\right)$ & $6.56^{\mathrm{a}} \pm 0.05$ & $6.61^{\mathrm{a}} \pm 0.06$ & $4.74^{c} \pm 0.06$ & $5.21^{\mathrm{b}} \pm 0.4$ \\
\hline & $\mathrm{Hb} \quad(\mathrm{g} / \mathrm{dl})$ & $12.50^{\mathrm{a}} \pm 0.07$ & $12.57^{\mathrm{a}} \pm 0.04$ & $7.44^{b} \pm 0.17$ & $7.30^{b} \pm 0.33$ \\
\hline & $\mathrm{PCV}(\%)$ & $41.38^{\mathrm{a}} \pm 0.06$ & $40.97^{\mathrm{a}} \pm 0.04$ & $27.01^{\mathrm{c}} \pm 0.19$ & $30.90^{\mathbf{b}} \pm 0.28$ \\
\hline & $\operatorname{MCV}(\mathrm{fl})$ & $63.13^{\mathrm{a}} 0.44$ & $61.98^{\mathrm{a}} \pm 0.61$ & $57.06^{\mathrm{c}} \pm 0.82$ & $59.34^{\mathrm{b}} \pm 0.46$ \\
\hline & $\mathrm{MCH}(\mathrm{pg})$ & $19.07^{\mathrm{a}} \pm 0.20$ & $19.03^{\mathrm{a}} \pm 0.21$ & $15.73^{\mathrm{b}} \pm 0.45$ & $14.00^{\mathrm{c}} \pm 0.55$ \\
\hline & $\mathrm{MCHC}(\mathrm{gm} / \mathrm{dl})$ & $30.21^{\mathrm{a}} \pm 0.17$ & $30.70^{\mathrm{a}} \pm 0.08$ & $27.54^{\mathrm{b}} \pm 0.58$ & $23.63^{\mathrm{c}} \pm 1.10$ \\
\hline \multirow{6}{*}{ 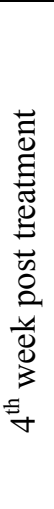 } & $\operatorname{RBCS}\left(\mathrm{X} 10^{6} / \mathrm{UL}\right)$ & $6.11^{\mathrm{a}} \pm 0.05$ & $6.09^{a} \pm 0.03$ & $4.28^{c} \pm 0.06$ & $4.67^{b} \pm 0.03$ \\
\hline & $\mathrm{Hb} \quad(\mathrm{g} / \mathrm{dl})$ & $12.74^{\mathrm{a}} \pm 0.12$ & $12.53^{\mathrm{a}} \pm 0.08$ & $7.23^{b} \pm 0.07$ & $7.28^{b} \pm 0.15$ \\
\hline & $\mathrm{PCV}(\%)$ & $39.38^{\mathrm{a}} \pm 0.10$ & $39.03^{\mathrm{a}} \pm 0.09$ & $25.15^{\mathrm{c}} \pm 0.20$ & $27.22^{b} \pm 0.23$ \\
\hline & $\operatorname{MCV}(\mathrm{fl})$ & $64.51^{\mathrm{a}} \pm 0.67$ & $64.10^{\mathrm{a}} \pm 0.40$ & $58.72^{b} \pm 0.93$ & $58.37^{\mathrm{b}} \pm 0.91$ \\
\hline & $\mathrm{MCH}(\mathrm{pg})$ & $20.87^{\mathrm{a}} \pm 0.23$ & $20.58^{\mathrm{a}} \pm 0.13$ & $16.89^{b} \pm 0.27$ & $15.62^{c} \pm 0.36$ \\
\hline & $\mathrm{MCHC}(\mathrm{gm} / \mathrm{dl})$ & $32.35^{\mathrm{a}} \pm 0.29$ & $32.10^{\mathrm{a}} \pm 0.28$ & $28.76^{\mathrm{b}} \pm 0.37$ & $26.75^{c} \pm 0.53$ \\
\hline
\end{tabular}

I: (non-infected non-treated group). II: (non- infected treated group)

III: (infected non-treated group). IV: (infected treated group) 
Table 2: Leukogram in mice infested with $S$. mansoni and or treated by curcumin (mean \pm S.E).

Data are presented as mean $\pm \mathrm{SE}, \mathrm{n}=5$ and values which have different letters are significantly differs from each other at $\mathrm{p} \leq 0.05$ using ANOVA test.

\begin{tabular}{|c|c|c|c|c|c|}
\hline parameter & groups & $\mathbf{I}$ & II & III & IV \\
\hline \multirow{5}{*}{ 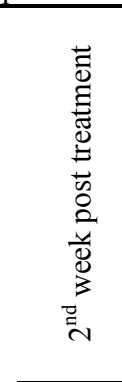 } & $\begin{array}{c}\text { TLC } \\
\left(\mathrm{X} 10^{3} / \mathrm{UL}\right)\end{array}$ & $8.22^{\mathrm{a}} \pm 0.20$ & $8.45^{\mathrm{a}} \pm 0.09$ & $6.74^{\mathrm{b}} \pm 0.12$ & $6.72^{\mathrm{b}} \pm 0.10$ \\
\hline & $\begin{array}{l}\text { LYMPHOCYTE } \\
\left(\mathrm{X} 10^{3} / \mathrm{UL}\right) \\
\end{array}$ & $5.19^{\mathrm{a}} \pm 0.13$ & $5.22^{\mathrm{a}} \pm 0.13$ & $4.41^{\mathrm{b}} \pm 0.08$ & $4.60^{\mathrm{b}} \pm 0.14$ \\
\hline & $\begin{array}{l}\text { NEUTROPHIL } \\
\left(\mathrm{X} 10^{3} / \mathrm{UL}\right) \\
\end{array}$ & $2.85^{\mathrm{a}} \pm 0.14$ & $3.10^{\mathrm{a}} \pm 0.06$ & $1.57^{\mathrm{b}} \pm 0.05$ & $1.69^{\mathrm{b}} \pm 0.07$ \\
\hline & $\begin{array}{l}\text { ESINOPHIL } \\
\left(\mathrm{X} 10^{3} / \mathrm{UL}\right) \\
\end{array}$ & $0.13^{\mathrm{c}} \pm 0.01$ & $0.20^{\mathrm{c}} \pm 0.01$ & $0.68^{\mathrm{a}} \pm 0.02$ & $0.39^{\mathrm{b}} \pm 0.04$ \\
\hline & $\begin{array}{l}\text { MONOCYTE } \\
\left(\mathrm{X} 10^{3} / \mathrm{UL}\right)\end{array}$ & $0.03^{\mathrm{b}} \pm 0.01$ & $0.02^{\mathrm{b}} \pm 0.00$ & $0.07^{\mathrm{a}} \pm 0.00$ & $0.03^{\mathrm{b}} \pm 0.00$ \\
\hline \multirow{5}{*}{ 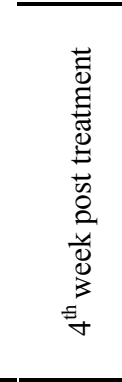 } & $\begin{array}{c}\text { TLC } \\
\left(\mathrm{X} 10^{3} / \mathrm{UL}\right) \\
\end{array}$ & $6.80^{\mathrm{ab}} \pm 0.34$ & $7.18^{\mathrm{a}} \pm 0.64$ & $5.40^{\mathrm{b}} \pm 0.53$ & $5.78^{\mathrm{ab}} \pm 0.63$ \\
\hline & $\begin{array}{l}\text { LYMPHOCYTE } \\
\left(\mathrm{X} 10^{3} / \mathrm{UL}\right)\end{array}$ & $4.84^{\mathrm{ab}} \pm 0.33$ & $5.09^{\mathrm{a}} \pm 0.60$ & $3.11^{\mathrm{b}} \pm 0.66$ & $3.96^{\mathrm{ab}} \pm 0.69$ \\
\hline & $\begin{array}{l}\text { NEUTROPHIL } \\
\left(\mathrm{X} 10^{3} / \mathrm{UL}\right)\end{array}$ & $1.80^{\mathrm{a}} \pm 0.14$ & $1.88^{\mathrm{a}} \pm 0.09$ & $1.38^{\mathrm{b}} \pm 0.18$ & $1.34^{\mathrm{b}} \pm 0.14$ \\
\hline & $\begin{array}{l}\text { ESINOPHIL } \\
\left(\mathrm{X} 10^{3} / \mathrm{UL}\right) \\
\end{array}$ & $0.12^{\mathrm{c}} \pm 0.01$ & $0.18^{\mathrm{c}} \pm 0.04$ & $0.81^{\mathrm{a}} \pm 0.07$ & $0.41^{b} \pm 0.06$ \\
\hline & $\begin{array}{l}\text { MONOCYTE } \\
\left(\mathrm{X} 10^{3} / \mathrm{UL}\right) \\
\end{array}$ & $0.03^{c} \pm 0.00$ & $0.02^{\mathrm{c}} \pm 0.00$ & $0.09^{\mathrm{a}} \pm 0.001$ & $0.07^{b} \pm 0.01$ \\
\hline
\end{tabular}

$\overline{\text { I: (non-infected non-treated group). II: (non- infected treated group) }}$

III: (infected non-treated group). IV: (infected treated group)

The significant $(\mathrm{p}<0.05)$ increase of serum AST, ALT, and ALP levels were observed in groups (III \& IV) when compared with control group (Table 3). On the other hand, group (IV) showed reduction in the serum enzymes level as compared to group (III). Serum levels of total protein, albumin and globulin were reduced significantly in groups (III \& IV) as compared to control group (Table 3). However Supplementation of curcumin to infected mice (group IV) resulted in elevation of total protein, albumin and globulin levels compared with infected non treated mice. Groups (III \& IV) showed significant increases of AFP and TNF-a compared with control group. However supplementation of curcumin to infected mice improved the both AFP and TNF- $\alpha$ levels as compared to infected non-treated mice (Table 4).

Table 3: Serum liver enzymes and proteinogram of mice infested with S. mansoni and or treated with curcumin (mean \pm S.E).

Data are presented as mean $\pm \mathrm{SE}, \mathrm{n}=5$ and values which have different letters are significantly differs from each other at $\mathrm{p} \leq 0.05$ using ANOVA test.

\begin{tabular}{|c|c|c|c|c|c|}
\hline parameters & groups & $\mathbf{I}$ & II & III & IV \\
\hline \multirow{6}{*}{ 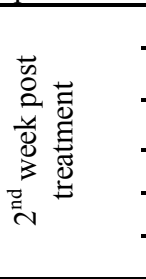 } & AST (IU/L) & $22.41^{\mathrm{c}} \pm 0.29$ & $21.36^{\mathrm{d}} \pm 0.15$ & $39.66^{\mathrm{a}} \pm 0.13$ & $28.72^{b} \pm 0.35$ \\
\hline & ALT(IU/L) & $19.30^{\mathrm{c}} \pm 0.62$ & $17.75^{\mathrm{c}} \pm 0.35$ & $29.89^{\mathrm{a}} \pm 0.63$ & $22.71^{\mathrm{b}} \pm 0.58$ \\
\hline & ALP(IU/L) & $38.42^{\mathrm{c}} \pm 0.24$ & $37.44^{\mathrm{d}} \pm 0.28$ & $58.31^{\mathrm{a}} \pm 0.36$ & $44.32^{b} \pm 0.23$ \\
\hline & Total protein $\mathrm{g} / \mathrm{dl}$ & $6.71^{\mathrm{a}} \pm 0.06$ & $6.79^{\mathrm{a}} \pm 0.09$ & $3.59^{\mathrm{c}} \pm 0.05$ & $4.61^{b} \pm 0.09$ \\
\hline & Albumin $\mathrm{g} / \mathrm{dl}$ & $2.42^{\mathrm{a}} \pm 0.21$ & $2.67^{\mathrm{a}} \pm 0.11$ & $1.19^{\mathrm{b}} \pm 0.14$ & $1.61^{\mathrm{b}} \pm 0.08$ \\
\hline & globulin g/dl & $3.94^{\mathrm{a}} \pm 0.19$ & $3.84^{\mathrm{a}} \pm 0.14$ & $2.13^{\mathrm{c}} \pm 0.16$ & $2.69^{b} \pm 0.09$ \\
\hline \multirow{6}{*}{ 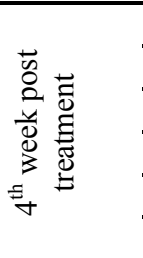 } & $\operatorname{AST}(\mathrm{IU} / \mathrm{L})$ & $34.56^{\mathrm{c}} \pm 0.56$ & $35.44^{\mathrm{c}} \pm .58$ & $67.82^{\mathrm{a}} \pm 0.79$ & $47.85^{b} \pm 0.98$ \\
\hline & ALT(IU/L) & $18.50^{\mathrm{d}} \pm 0.33$ & $21.45^{\mathrm{c}} \pm 0.34$ & $68.52^{a} \pm 0.49$ & $32.26^{\mathrm{b}} \pm 0.35$ \\
\hline & ALP(IU/L) & $35.67^{\mathrm{c}} \pm 0.57$ & $32.17^{\mathrm{d}} \pm 0.41$ & $72.06^{\mathrm{a}} \pm 0.62$ & $46.43^{b} \pm 0.49$ \\
\hline & Total protein $\mathrm{g} / \mathrm{dl}$ & $6.57^{\mathrm{a}} \pm 0.15$ & $6.78^{\mathrm{a}} \pm 0.12$ & $3.87^{\mathrm{c}} \pm 0.11$ & $4.89^{b} \pm 0.32$ \\
\hline & albumin $\mathrm{g} / \mathrm{dl}$ & $2.40^{\mathrm{a}} \pm 0.14$ & $2.49^{\mathrm{a}} \pm 0.11$ & $1.46^{\mathrm{b}} \pm 0.08$ & $1.66^{\mathrm{b}} \pm 0.06$ \\
\hline & globulin g/dl & $3.83^{\mathrm{a}} \pm 0.18$ & $3.95^{\mathrm{a}} \pm 0.14$ & $2.27^{\mathrm{c}} \pm 0.15$ & $2.94^{\mathrm{b}} \pm 0.30$ \\
\hline
\end{tabular}

I: (non-infected non-treated group). II: (non- infected treated group)

III: (infected non-treated group). IV: (infected treated group) 
Table 4: Serum AFP and TNF of mice infested with $S$. mansoni and /or treated with curcumin (mean \pm S.E). Data are presented as mean $\pm \mathrm{SE}, \mathrm{n}=5$ and values which have different letters are significantly differs from each other at $\mathrm{p} \leq 0.05$ using ANOVA test.

\begin{tabular}{|c|c|c|c|c|c|}
\hline $\begin{array}{r}\mathrm{g} \\
\text { parameters }\end{array}$ & & $\mathbf{I}$ & II & III & IV \\
\hline \multirow{2}{*}{ 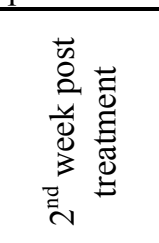 } & AFP & $7.64^{\mathrm{c}} \pm 0.10$ & $7.00^{c} \pm 0.39$ & $38.65^{\mathrm{a}} \pm 0.72$ & $30.12^{\mathrm{b}} \pm 0.54$ \\
\hline & TNF & $12.45^{\mathrm{c}} \pm 0.30$ & $11.48^{\mathrm{c}} \pm 0.32$ & $33.32^{\mathrm{a}} \pm 0.50$ & $24.71^{b} \pm 0.27$ \\
\hline \multirow{2}{*}{ 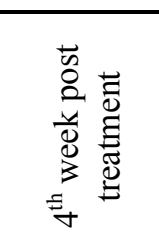 } & AFP & $8.87^{\mathrm{c}} \pm 0.47$ & $8.51^{c} \pm 0.57$ & $50.44^{\mathrm{a}} \pm 0.70$ & $41.96^{\mathrm{b}} \pm 0.23$ \\
\hline & TNF & $12.35^{\mathrm{c}} \pm 0.40$ & $10.76^{\mathrm{c}} \pm 0.37$ & $48.41^{\mathrm{a}} \pm 0.87$ & $40.72^{b} \pm 1.08$ \\
\hline
\end{tabular}

I: (non-infected non-treated group). II: (non- infected treated group)

III: (infected non-treated group). IV: (infected treated group)

Groups (III \& IV) showed increased levels of serum TC \&TG and LDL-C as compared to control group (Table 5). There was significant decrease in HDL-C groups (III \& IV) in the first period. On the other hand, curcumin supplementation to the infected mice lowered the serum TC \&TG and LDL-C concentrations as compared to infected group.

Table 5: Serum lipid profile of mice infested with S. mansoni and /or treated with curcumin (mean \pm S.E).

\begin{tabular}{|c|c|c|c|c|c|}
\hline parameter & ups & $\mathbf{I}$ & II & III & IV \\
\hline \multirow{4}{*}{ 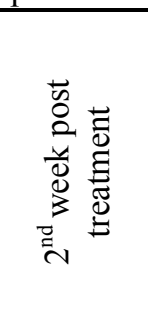 } & Cholesterol (mg/dl) & $84.32^{\mathrm{c}} \pm 1.21$ & $79.80^{\mathrm{c}} \pm 1.77$ & $114.85^{\mathrm{a}} \pm 3.70$ & $99.52^{\mathrm{b}} \pm 1.71$ \\
\hline & triglycerides $(\mathrm{mg} / \mathrm{dl})$ & $57.54^{\mathrm{c}} \pm 1.12$ & $51.11^{\mathrm{c}} \pm 3.67$ & $79.03^{\mathrm{a}} \pm 2.24$ & $68.21^{b} \pm 1.93$ \\
\hline & HDL-C (mg/dl) & $16.18^{\mathrm{a}} \pm 0.60$ & $17.47^{\mathrm{a}} \pm 0.69$ & $13.25^{\mathrm{b}} \pm 0.68$ & $13.30^{\mathrm{b}} \pm 0.91$ \\
\hline & LDL-C (mg/dl) & $56.63^{\mathrm{c}} \pm 1.32$ & $52.21^{\mathrm{c}} \pm 2.07$ & $85.78^{\mathrm{a}} \pm 3.54$ & $72.73^{\mathrm{b}} \pm 1.58$ \\
\hline \multirow{4}{*}{ 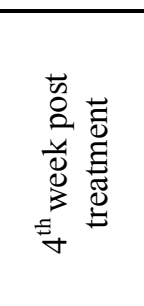 } & Cholesterol (mg/dl) & $84.26^{\mathrm{c}} \pm 1.01$ & $81.86^{\mathrm{c}} \pm 1.27$ & $140.65^{\mathrm{a}} \pm 1.61$ & $114.73^{b} \pm 2.08$ \\
\hline & triglycerides $(\mathrm{mg} / \mathrm{dl})$ & $46.16^{\mathrm{c}} \pm 0.70$ & $45.48^{\mathrm{c}} \pm 2.59$ & $66.82^{\mathrm{a}} \pm 1.87$ & $52.70^{\mathrm{b}} \pm 1.41$ \\
\hline & HDL-C (mg/dl) & $21.13^{\mathrm{a}} \pm 0.71$ & $22.42^{\mathrm{a}} \pm 1.19$ & $19.76^{\mathrm{a}} \pm 0.76$ & $20.27^{\mathrm{a}} \pm 0.83$ \\
\hline & LDL-C (mg/dl) & $53.89^{c} \pm 1.53$ & $50.34^{\mathrm{c}} \pm 2.41$ & $107.52^{\mathrm{a}} \pm 1.20$ & $83.91^{b} \pm 2.21$ \\
\hline
\end{tabular}

Data are presented as mean \pm SE, $n=5$ and values which have different letters are significantly differs from each other at $\mathrm{p} \leq 0.05$ using ANOVA test.

I: (non-infected non-treated group). II: (non- infected treated group)

III: (infected non-treated group). IV: (infected treated group)

Results shown in (table 6) indicated that the content of reduced glutathione was significantly $(\mathrm{P}<0.05)$ decreased in hepatic tissue of group (III) compared to control group (Table 6). Supplementation of diet with curcumin (group II) caused a significant $(\mathrm{P}<0.05)$ increase in the content of reduced glutathione compared with both of control and infected non-treated groups (group I and group III). Infected mice supplemented with curcumin (group IV) partially restored the content of reduced glutathione to the normal values. Tables (6) showed that the activities of liver tissue SOD and CAT of group (III) significantly decreased $(\mathrm{P}<0.05)$ as compared to control group. Treatment of non-infected mice with curcumin (group II) significantly increased the activities of liver tissue SOD and CAT as compared to that of group (III). 
Table 6: Levels of GSH, SOD and CAT in liver tissue homogenates of mice infested with S. mansoni and /or treated with curcumin (mean \pm S.E).

Data are presented as mean \pm SE, $n=5$ and values which have different letters are significantly differs from each other at $\mathrm{p} \leq 0.05$ using ANOVA test.

\begin{tabular}{|c|c|c|c|c|c|}
\hline parameters & groups & $\mathbf{I}$ & II & III & IV \\
\hline \multirow{3}{*}{ 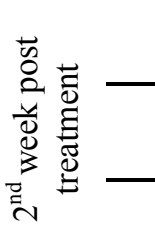 } & GSH & $30.49^{b} \pm 0.29$ & $32.44^{\mathrm{a}} \pm 0.30$ & $13.48^{\mathrm{d}} \pm 0.23$ & $24.21^{\mathrm{c}} \pm 0.21$ \\
\hline & SOD & $23.60^{\mathrm{a}} \pm 0.21$ & $24.23^{\mathrm{a}} \pm 0.49$ & $14.32^{\mathrm{c}} \pm 0.24$ & $17.55^{b} \pm 0.29$ \\
\hline & CAT & $67.33^{\mathrm{b}} \pm 0.27$ & $70.47^{\mathrm{a}} \pm 0.40$ & $53.39^{\mathrm{d}} \pm 0.54$ & $61.58^{\mathrm{c}} \pm 0.40$ \\
\hline \multirow{3}{*}{ 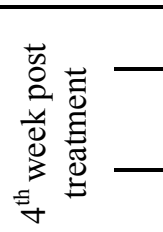 } & GSH & $34.70^{\mathrm{b}} \pm 0.29$ & $35.81^{\mathrm{a}} \pm 0.33$ & $18.77^{\mathrm{d}} \pm 0.41$ & $25.71^{\mathrm{c}} \pm 0.23$ \\
\hline & SOD & $21.71^{\mathrm{a}} \pm 0.31$ & $20.02^{\mathrm{b}} \pm 0.44$ & $11.81^{\mathrm{d}} \pm 0.22$ & $14.94^{\mathrm{c}} \pm 0.27$ \\
\hline & CAT & $70.82^{\mathrm{a}} \pm 1.23$ & $72.01^{\mathrm{a}} \pm 0.83$ & $48.91^{\mathrm{b}} \pm 1.02$ & $51.75^{b} \pm 1.80$ \\
\hline
\end{tabular}

I: (non-infected non-treated group). II: (non- infected treated group)

III: (infected non-treated group). IV: (infected treated group)

\section{DISCUSSION}

The erythrogram, in the present work, showed microcytic hypochromic anemia in groups (III \& IV) all over the experimental periods (Table 1). This sign marked from a significant decrease in all of the erythrocytic parameters (the mean values of RBCs count, $\mathrm{PCV}, \mathrm{Hb}$ concentration, $\mathrm{MCV}, \mathrm{MCH}$ and $\mathrm{MCHC}$ ) in groups (III \& IV all over the experiment as compared to control group, such decrease was more outstanding in infected non treated group (group III) than infected treated group (group IV). Our results are in agreement with that obtained by Abd EL-Mottaleb et al. (2008) and Nahla et al. (2008), who recorded a significant decrease in the erthrocytic count and blood indices accompanied with schistosoma infection.

On the contrary our results are disagree with that reported by Bugarski et al. (2006) who mentioned insignificant changes in any of the erythrogram parameters. This may be attributed to difference in parasitis species and the dose of parasitic infestation.

Administration of curcumin, to non-infected animal group (II) showed an insignificant change in RBC count as compared to control group. The infected mice treated with curcumin, showed an improvement in erythrogram values (PCV, MCV, MCH and $\mathrm{MCHC}$ ) as compared to infected non-treated group. Sharma et al. (2011) proved that curcumin administration to infected mice improved the erythrocytic count, $\mathrm{Hb}$ and blood indices.
Decrease in RBCS count may be returned to the reduction in erythropoiesis in bone marrow and faster rate of destruction of peripheral RBC in spleen (Coles 1986). Decrease in Hb can be related to reduction in size of RBC, impaired biosynthesis of heam in bone marrow or due to reduction in the rate of formation of RBCS. Sturrock et al. (1996) attributed the presence of anemia to chronic blood loss that result from the bleeding induced by migration of worms through intestinal wall or due to blood consumption by adult schistosomes.

Table (2) illustrates total (TLC) and differential leukocyte count (Lymphocyte, Neutrophil, Esinophil and Monocytic count) in control and experimental groups of animals. Both of infected non-treated and infected treated groups showed leucopenia as compared to control group although supplementation of curcumin to non-infected mice improved the WBCs count compared to control group. These results agree with El-sheikha et al. (2008) who recorded significant decrease in total leucocytic count in infected mice with Schistosomiasis. In contrast to this result, Abd EL-Mottaleb et al. (2008) and Willingham et al. (1998) who noticed non-significant change in total leucocytic count in all experimental groups. Allam 2009 demonstrated that infected treated mice showed insignificant alteration in total leukocytic count. The difference may be due to difference of infestation dose and or experimental period. Supplementation of curcumin to non-infected mice showed insignificant increase in total leucocytes. 
These results agree with Antony et al. (1999) who proved that Curcuma longa extract administration increased the total lecuocytic count in Balb/c mice due to the immune-stimulating activity of Curcumin.

On regarding the differential leucocytic count, our results revealed neutropenia, lymphopenia and eosinophilia in groups (III \& IV) when compared with control group (Table 2). Similar results were obtained by Bugarski et al. (2006) who reported a significant neutropenia and esinophilia. Also these results are in accordance with that obtained by Abd EL-Mottaleb et al. (2008), Sharma et al. 2011, Ver cruysse et al. (1988) and Nahla et al. (2008) who found neutropenia, lymphopenia and eosinophilia accompanied parasitic infection. Simultaneously, a significant neutropenia and lymphopenia were observed, which could be ascribed to the recruitment of these cells to the site of the infection (Bugarski et al., 2006). Otherwhile Abd EL-Mottaleb et al. (2008) mentioned that the eosinophilia may be due to the powerful defense reaction and allergic manifestation against Schistosoma mansoni and their eggs. From the same side, animals were primarily characterized by the appearance of eosinophilia, which was not unexpected since eosinophilia is the most frequent response to helminths Klion and Nutman (2004).

Supplementation of curcumin to non-infected mice insignificantly increased neutrophil, esinophil and lymphocytic count as compared to control group. The results showed insignificant changes of neutrophil, leucocyte and eosinophil in infected treated mice group when compared to infected non-treated group. Sharma et al. 2011 recorded that curcumin may stabilize the cell membrane and restore various blood variables.

Hepatic damage can affect the metabolic processes in the body due to the role of liver in general metabolism. Enzymes are necessary for normal cellular metabolism including that of the liver (Rajamanickam and Muthuswamy, 2008). Hepatoprotective activity of curcumin was evaluated on Schistosoma mansoni infected mice by estimation of serum hepatic enzymes. Hepatic cells appear to participate in a variety of enzymatic metabolic activities. Infection of Schistosoma mansoni damages the hepatic cells leading to a significant increase in serum levels of AST, ALT, and ALP respectively (Table 3). The significant $(\mathrm{p}<0.05)$ increase of serum AST, ALT, and ALP levels were observed in group (III) when compared with control group. On the other hand, group (IV) showed reduction in the serum enzymes level as compared to group (III).

These results are in agreement with previously reported by El-Gowhary et al. (1993). Allam (2009) reported that, infected mice treated with curcumin restore the hepatic ALT and AST activities that were decreased by $S$. mansoni infection. This amelioration in the activities of liver enzymes could be attributed to the reduction in hepatic granuloma size and fibrosis as well as absence of necrotic hepatic tissue in infected treated mice (Allam, 2009). Apparently it appears that the membrane damage seems to be the prime culprit for the marked increase in the serum marker enzymes, AST, ALT, and ALP (Naik et al., 2011).

Serum levels of total protein, albumin and globulin were reduced significantly in group (III) as compared to control group (Table 3). However Supplementation of curcumin to infected mice (group IV) resulted in elevation of total protein, albumin and globulin levels compared with infected non treated mice. Similar observations were noticed by El-Ansary et al. (2007) and El-Emam et al. (2011). These results supported through the work of El-Heig et al. (1977) who recorded a marked decrease of protein content in $S$. mansoni infected mice.

Alfa-fetoprotein (AFP) is a glycoprotein, of unknown function, normally produced during neonatal development by the liver and in small concentrations by the gastrointestinal tract (Abelev et al., 1963). Abnormal serum level of AFP has been reported in patients with liver cirrhosis and hepatocellular carcinoma (Gupta et al., 2003). So our work was extended to observe the effect of both Schistosoma infection and administration of curcumin on serum alfa-fetoprotein (AFP) and, tumor necrosis factor-alfa (TNF- $\alpha$ ) (Table 4). Infected non treated mice showed significant increases of AFP and TNF-a compared with control group. However supplementation of curcumin to infected mice improved the both AFP and TNF- $\alpha$ levels as compared to infected nontreated mice. These results agreed with that observed by El-Rigal et al. (2011), Who recorded elevated level of AFP in sera of $S$. mansoni infected mice which may be considered as an index for liver fibrosis related to Schistosomiasis.

Tumor necrosis factor-alpha (TNF- $\alpha$ ) is a cytokine involved in systemic inflammation and is a member of a group of cytokines that stimulate the acute phase reaction. Torben and Hailu (2007) stated that increased level of this inflammatory cytokine after egg excretion may be an indication of its effect in complications of Schistosomiasis, it is capable of inducing tissue injury and fibrosis. The results showed in table (4) indicated that, TNF- $\alpha$ is increased in serum of infected non treated mice compared to control group. The infected mice group treated with curcumin showed an improvement in serum TNF- $\alpha$ level compared with infected non treated mice. These results agree with that obtained by El-Rigal et al. 2011 and Allam 2009 who observed that infected 
mice treated with curcumin revealed low serum level tumor necrosis factor alpha (TNF-a).

In order to investigate the hypolipidemic effects of curcumin on $S$. mansoni infected mice, quantitative assay of lipid profile was conducted by measuring the concentrations of serum total cholesterol (TC) \& triglycerides (TG) and lipoproteins HDL-C and LDLC. The infected non trated mice showed increased levels of serum TC \&TG and LDL-C as compared to control group (Table 5). There was significant decrease in HDL-C in the first period in groups (III \& IV). On the other hand, curcumin supplementation to the infected mice lowered the serum TC \& TG and LDL-C concentrations as compared to infected group. These results are in accordance with that obtained by Arafa (2005) while opposite to that reported by Baum et al. (2007).

Similar observation were recorded by Godkar et al. (1996) who investigated that supplementation of curcumin in diet of Swiss mice caused a marked decrease of serum TC \&TG level. The mechanism by which curcumin decreased serum cholesterol in previous study is not known. One hypothesis is that curcumin prevents the increase in serum cholesterol in the animal studies by inhibiting dietary cholesterol absorption (Arafa, 2005). Curcumin was reported to cause a little increase of plasma HDL-C in rats (Arafa, 2005). Otherwise Kang and Chen (2009) provide a novel insights into the roles and mechanisms of curcumin in lowering the level of LDL-C that include curcumin suppressed LDL-R receptor gene expression in activated hepatic stellate cells.

Reduced glutathion (GSH) are thought to play a vital role in protecting cells against reactive oxygen. During the metabolic action of GSH, its sulfhydryl group becomes oxidized resulting with the formation of corresponding disulfide compound, GSSG. Thus depletion of GSH content is associated with an increase in GSSG concentration resulting with the depletion in GSH/GSSG ratio. The content of reduced glutathione was significantly $(\mathrm{P}<0.05)$ decreased in hepatic tissue of infected non treated mice group compared to control group (Table 6). Supplementation of diet with curcumin (group II) caused a significant $(\mathrm{P}<0.05)$ increase in the content of reduced glutathione compared with both of control and infected non-treated groups (group I and group III). Infected mice supplemented with curcumin (group IV) partially restored the content of reduced glutathione to the normal values. Similar protective effect of curcumin pretreatment that showed a powerful antioxidant effect; it notably elevated GSH concentration and attenuated cellular ALT and AST released from hepatocytes reported by Naik et al. (2004). The decreases in GSH level of infected mice is in agreement with the findings of Leelank and
Bansal (1996), who reported GSH depletion decreases the GSH/GSSG ratio and production of free radicals. These free radicals interact with membrane lipids leading to the production of lipid hydroperoxides.

Tables (6) showed that the activities of liver tissue SOD and CAT of infected non treated mice significantly decreased $(\mathrm{P}<0.05)$ as compared to control group. Treatment of non-infected mice with curcumin (group II) significantly increased the activities of liver tissue SOD and CAT as compared to that of infected mice. In addition, a significant recovery relating to liver tissue SOD and CAT was observed in infected mice supplemented curcumin (El-Demerdash et al., 2009). Also, Rizk (1998) and Allam (2009) reported that catalase activity was enhanced in infected mice treated with curcumin. The antioxidant enzymes superoxide dismutase and catalase play an important role in keeping homeostasis and protection against oxidative damage by removing the toxic free radicals in vivo (EI Shenawy et al., 2008 and Jia et al., 2009). Recently, Rizk et al. (2012) noticed that the reduction in catalase activity could be attributed to its utilization in scavenging the free radicals overload which generated during Schistosomiasis. A decrease of SOD activity can be resulted from increased removal of superoxide anions (Sharma et al., 2005). The levels of antioxidant enzymes are known to be elevated in cells in response to free radical production (Bandyopadhyay et al., 1999).

These results coincide with that of Cerny et al. (2011) who observed plasma catalase activity as a marker of oxidative stress was 2.4-fold elevated as compared to control and this level further increased to 3-fold following curcumin treatment. Priyadarsini (1997) and Masuda et al. (1999) indicated that the exact mechanism of antioxidant activity of curcumin is not clear, while it is known to react with glutathione and also undergo dimerization by interacting with free radicals. Naik et al. (2011) and Kurup et al. (2007) attributed the antioxidant property of curcumin extract to the presence of chemical groups like hydroxyl methoxy and 1,3-diketone conjugated diene system. Naik et al. (2011) believed that the antioxidant activity of curcumin might be directly or indirectly associated with the maintenance or preservation of membrane integrity, which might help to prevent the elevation of serum marker enzymes observed during inflammation.

According to our results we concluded that curcumin, could not be used as an anti-parasitic whereas it only improves the alterations of hematological, biochemical, antioxidants parameters previously induced in schistosoma mansoni infected mice. 


\section{REFERENCES}

Abd EL-Mottaleb, E.M.; El-Gharieb, H.H. and Abdel Rahman, M.A.M. (2008): Parasitological and Clinico-Pathological Studies on Some Herbal Preparations in Mice Experimentally Infected With Schistoma mansoni. Egypt. J. Comp. path Clinic. Path., 12(2), 269-299.

Abelev, G.1.; Perova, S.D.; Khramkova, N.1.; Postnikova, Z.A. and Irlin, LS. (1963): Production of embryonal a-globulin by transplantable mouse hepatomas. Ransplantation., 1,174-180.

Aebi, H. (1974): Catalase. Bergmeyer, H.U. (Ed.), Methods of Enzymatic Analysis, vol. 2. Academic Press, New York, pp. 673-678.

Aggarwal, B.B. and Harikumar, K.B. (2009): Potential therapeutic effects of curcumin, the anti-inflammatory agent, against neurodegenerative, cardiovascular, pulmonary, metabolic, autoimmune and neoplastic diseases. Int. J. Biochem. Cell Biol., 41, 40-59.

Allam, G. (2009): Immunomodulatory effects of curcumin treatment on murine Schistosomiasis mansoni. Immunobiology., 214, 712-27.

Arafa, H.M. (2005): Curcumin attenuates diet induced hypercholesterolemia in rats, Med. Sci. Mon. i, 11,228-34.

Antony, S.; Kuttan, R. and Kuttan, G. (1999): Imunomodulatory activity of curcumin. Immunol. Invest., 28, 291-303.

Bandyopadhyay, U.; Das, D. and Banerjee, R.K. (1999): Reactive oxygenspecies: oxidative damage and pathogenesis. Current Science., 77, 658-666.

Baum, L.; Cheung, S.K.; Mok, V.C.; Lam, L.C.; Leung, V.P.; Hui, E.; Ng, C.C.; Chow, M.; Ho, P.C.; Lam, S.; Woo, J.; Chiu, H.F.; Goggins, W.; Zee, B.; Wong, A.; Mok, H.; Cheng, WK.; Fong, C.; Lee, J.S.; Chan, M.H.; Szeto, S.S.; Lui, V.W.; Tsoh, J.; Kwok, T.C.; Chan, I.H. and Lam, C.W. (2007): Curcumin effects on blood lipid profile in a 6-month human study. Pharmacol Res., 56(6), 509-14.

Bergquist, N.R. and Colley, D.G. (1998): Schistosomiasis vaccines: research to development, Parasitol., 14, 99-104.

Bugarski, D.; Jov, G.IC.; Katic'-Radivojevic', S.; Petakov, M.; Krstic', A.; Stojanovic', A. and Milenkovic', P. (2006): Hematopoietic changes and altered reactivity to IL-17 in Syphacia obvelata-infected mice. Parasitology International., 55, 91-97.

Černy, D.; Lekić, N.; Vaňova, K.; Muchova, L.; Kmoničkova, E.; Zidek, Z.; Kamenikova, L.; Hořinek, A. and Farghali, H. (2011): Hepatoprotective effect of curcumin in lipopolysaccharide/D-galactosamine model of liver injury in rats: Relationship to $\mathrm{HO}-1 / \mathrm{CO}$ antioxidant system. Fitorapia., 82, 786-791

Chen, A. and Zheng, S. (2008): Curcumin inhibits connective tissue growth factor gene expression in activated hepatic stellate cells in vitro by blocking NF-kappaB and ERK signalling. Br. J. Pharmacol., 153, 557-567.

Coles, E.H. (1986): Veterinary Clinical Pathology $4^{\text {th }}$ ed. W.B. Saunders Company, Philadelphia, London, Toronto, Mexico, Sydney, Tokyo, Hong Kong.

Doumas, B.T.; Baysa, D.D.; Carter, R.J.; Peters, T. and Schaffer, R. (1981): Determination of seum total protein. Clin. Chem., 27., 1642.

Doumas, B.T. and Biggs, H.G. (1972): Determination of serum globulin in: Standerd Methods of Clinical Chemistry Vol. 7 Edited by Cooper, New York, Academic Press.

EDKC, E. and der deutschen, G.F.K. (1972): "Kinitic determinations of alkaline phos phatase activity as recom- mended by the German clinical Society." Z. Klin Chem Biochem., 10, 182.

El-Agamy, D.S.; Shebl, A.M. and Said, S.A. (2011): Prevention and treatment of Schistosoma mansoni-induced liver fibrosis in mice. Inflammopharmacology., 19, 307-16.

El-Ansary, A.K.; Ahmed, S.A. and Aly, S.A. (2007): Antischistosomal and liver protective effects of Curcuma longa extract in Schistosoma mansoni infected mice. Indian Journal of Experimental Biology., 45, 791-801.

El-Banhawey, M.A.; Ashry, M.A.; El-Ansary, A.K. and Aly, S.A. (2007): Effect of Curcuma longa or praziquantel on Schistosoma mansoni infected mice liver-histological and histochemical study. Indian J Exp Biol., 45(10), 877-889.

El-Demerdash, F.M.; Yousef, M.I. and Radwan, F.M. E. (2009): Ameliorating effect of curcumin on sodium arsenite-induced oxidative damage and lipid peroxidation in different rat organs Food and Chemical Toxicology., 47, 249-254.

El-Emama, M.; Momeana, B.M.; Wafaa, L.I.; Basma, M.AE.; Alaa, A. and Youssef, A.A. (2011): Biological and biochemical parameters of Biomphalaria alexandrina snails exposed to the plants Datura stramonium and Sesbania sesban as water suspensions of their dry powder. Pesticide Biochemistry and Physiology., 99 (1) 96-104.

El-Gowhary, S.H.; Rahmy, A.E.; El-azzouni, M.Z.; Nagil, A.I. and El-Medany, A. (1993): Oral contraceptive pills in experimental Schistosomiasis manosoni parasitology, biochemical, histopathogical and ultrastructural studies. J. Egypt Soc. Parasitol., 23, 609.

El-Haieg, M.O.; Ibrahim, II. and Zanaty, M.F. (1977): Alpha-fetoprotein in adult normal, 
bilharzial hepatic fibrosis and viral hepatitis. Egypt. J. Egypt Med. Assoc., 60,699.

El-Khoby, T.; Galal, N.; Fenwick, A.; Barakat, R.; El-Hawey, A.; Nooman, Z.; Habib, M. and Dewolfe Miller, F. (2000): The epidemiology of schistosomiasis in Egypt:summary findings in nine governorates. American Journal of Tropical Medicine and Hygiene., 62, 88-99.

Ellman, G.L. (1959): Tissue sulfhydryl groups. Archives of Biochemical and Biophysics., 82, 70-77.

EI-Rigal, N.S.; Nadia, M.M.; Azza, M.M.; Naema, Z.M. and Z. Maha Z.R. (2011): Protection against oxidative damage induced by Schistosoma mansoni using susceptible/ resistant nucleoproteins from Biomphalaria alexandrina snails. Asian Journal of Biological Sciences., 4 (5), 445-456.

El-sheikha, H.M.; Hussein, S. and Rahbar, M.H. (2008): Clinico-pathological effects of Schistosoma mansoni infection associated with simultaneous exposure to malathion in Swiss outbred albino mice. Acta Tropica, 108:11-19.

EI-Shenawy, N.S.; Soliman, M.F. and Reyad, S.I. (2008): The effect of antioxidant properties of aqueous garlic extract and Nigella sativa as anti-schistosomiasis agents in mice. Rev. Inst. Med. Trop. Sao Paulo., 50, 29-3654.

Feldman, B.F.; Zinkl, J.G. and Jain, N.C. (2000): "Schalm's Veterinary Hematology" 5th Ed., Philadelphia, London.

Friedewald, W.T.; Levy, R.I. and Fredrickson, D.S. (1972): Estimation of the concentration of low-density lipoproteins cholesterol in plasma without use of the ultracentrifuge. Clin Chem., 18, 499-502.

Fu, Y.; Zheng, S.; Lin, J.; Ryerse, J. and Chen, A. (2008): Curcumin protects the rat liver from $\mathrm{CCl}$-caused injury and fibrogenesis by attenuating oxidative stress and suppressing inflammation. Mol. Pharmacol., 73, 399-409.

Godkar, P.B.; Narayanan, P. and Bhid, S.V. (1996): Hypocholesterolemic effect of turmeric extract on Swiss mice. Indian J Pharmaco., 28(3) 171-174.

Gryseels, B.; Polman, K.; Clerinx, J. and Luc, K. (2006): Human schistosomiasis. Lancet., 368(9541), 1106-1118.

Gupta, S.; Bent, S. and Kohlwes, J. (2003): Test characteristics of a-fet.oprotein for detecting hepatocellular carcinoma in patients with hepatitis C: Asystematic review and critical analysis. Ann. Internal Med., 139, 46-50.

Jia, J.; Zhang, X.; Hu, Y.; Wu, Y. and Wang, $Q$. (2009): Evaluation of in vivo antioxidants activities of Ganoderma lucidum polysaccharides in STZ-diabetic rats. Food Chern., 115, 32-36.

Kang, Q. and Chen, A. (2009): Curcumin suppresses expression of low density lipoprotein (LDL) receptor, leading to the inhibition of LDLinduced activation of hepatic stellate cells British Journal of Pharmacology., 157, 1354-1367.

Klion, A.D. and Nutman, T.B. (2004): The role of eosinophils in host defense against helminth parasites. J Allergy Clin Immunol., 113, 30-7.

Kurup, V.P.; Barrios, C.S.; Raju, R.; Johnson, B.D.; Levy, M.B. and Fink, J.N. (2007): Immune response modulation by curcumin in a latex allergy model. Clin Mol Allergy., 5, 1.

Leclercq, I.A.; Farrell, G.C.; Sempoux, C.; dela, Pena, A. and Horsmans, Y. (2004): Curcumin inhibits NF-kappaB activation and reduces the severity of experimental steatohepatitis in mice. J. Hepatol., 41, 926-34.

Leelank, B.N. and Bansal, M.P. (1996): Effect of selenium supplementation on the glutathione redox system in the kidney of mice after chronic cadmium exposures. Journal Applied Toxicology., 17, 81-84.

Lin, J. and Chen, A. (2008): Activation of peroxisome proliferator activated receptorgamma by curcumin blocks the signaling pathways for PDGF and EGF in hepatic stellate cells. Lab Invest., 88, 529-40.

Magalhães, L.G.; Machado, C.B.; Morais, E.R.; Moreira, E.B.; Soares, C.S.; da Silva, S.H.; Da Silva, F.A.A. and Rodrigues, V. (2009): In vitro schistosomicidal activity of curcumin against Schistosoma mansoni adult worms. Parasitol Res., 104(5), 1197-1201.

Magnussen, P. (2003): Treatment and re-treatment strategies for schistosomiasis control in different epidemiological settings: a review of 10 years' experiences. Acta Trop., 86, 243-254.

Masuda, T.; Hidaka, K.; Shinohar, A.; Maekawa, T.; Takeda, Y. and Yamaguchi, H. (1999): Chemical studies in antioxidant mechanism of curcuminoids: analysis of radical reaction products from curcumin. Journal of Agriculture and Food Chemistry., 47, 71-77.

Melman, S.D.; Steinauer, M.L.; Cunningham, C.; Kubatko, L.S.; Mwangi, I.N.; Wynn, N.B.; Mutuku, M.W.; Karanja, D.M.; Colley, D.G.; Black, C.L.; Secor, W.E.; Mkoji, G.M. and Loker, E.S. (2009): Reduced susceptibility to praziquantel among naturally occurring Kenyan isolates of Schistosoma mansoni. PLoS Negl. Trop. Dis., 3, 504.

Morais, E.R.; Oliveira, K.C.; Magalhãe, L.G.; Moreira, E.B.C.; Sergi, V.A. and Rodrigues, V. (2013): Effects of curcumin on the parasite Schistosoma mansoni: A transcriptomic Approach. Molecular and Biochemical Parasitology.187, 91-97.

Nahla, S.E.; Maha, F.M.S. and Shimaa, I.R. (2008): The effect of antioxidant proper- ties of aqueous garlic extract and Nigella sativa as 
anti- schistosomiasis agents in mice." Rev. Inst. Med. Trop. S. Paulo., 50, 10.

Naik, S.R.; Thakare, V.N. and Patil, S.R. (2011): Protective effect of curcumin on experimentally induced inflammation, hepatotoxicity and cardiotoxicity in rats: Evidence of its antioxidant property. Experimental and Toxicologic Pathology., 63, 419-431.

Naik, R.S.; Mujumdar, A.M. and Ghaskadbi, S. (2004): Protection of liver cells from ethanol cytotoxicity by curcumin in liver slice culture in vitro. Journal of Ethnopharmacology., 95, 31-37.

Paolett, F. and Mocali, A. (1990): Determination of superoxide dismutase activity by purely chemical system based on NAD $(\mathrm{P}) \mathrm{H}$ oxidation. Methods Enzymol., 186, 209-220.

Priyadarsini, K.I. (1997): Free radical reaction of curcumin in membrane models. Free Radical Biology and Medicine., 23, 838-843

Rajamanickam, V. and Muthuswamy, N. (2008): Effect of heavy metals induced toxicity on metabolic biomarkers in common carp (Cyprinus carpio L.). Maejo Int. J. Sci. Tech., 2(01), 192-200.

Reitmans, S. and Frankel, S.L. (1957): colorimetric method for the determination of serum glutamic oxalacetic and glutamic pyruvic transaminases., Amer. J. Clin. Pathol., 28, 56-63.

Reyes-Gordillo, K.; Segovia, J.; Shibayama, M.; Vergara, P.; Moreno, M.G. and Muriel, P. (2007): Curcumin protects against acute liver damage in the rat by inhibiting NF-kappaB, proinflammatory cytokines production and oxidative stress. Biochim Biophys Acta., 1770, 989-96.

Richmond, W. (1973): Enzymatic determination of cholesterol. Clin. Chem., 19, 1350-1365.

Rizk, M.; Ibrahim, N. and El-Rigal, I.N. (2012): Comparative In vivo antioxidant levels in schistosoma mansoni infected mice treated with praziquantel or the essential Oil of Melaleuca armillaris leaves. Pakistan Journal of Biological Sciences., 15 (20), 971-978.

Rizk, M. (1998): Protective effect of Curcuma longa against oxidative stress in Schistosoma mansoni infected mice livers. Egypt. I. Bilh., 21, 1-8.

Silva, M.; Rodrigues, V.; Albuquerque, S.; Bastos, J.K.; Silva, R.; Pereira Junior, O.S.; Bianco, T.N.C.; Cunha, W.R.; Santos, F.F.; Donate, P.M.; Magalhaes, L.G.; Pereira, A.C. and Da Silva, F.A.A. (2009): In vitro antischistosomal activities of phenylpropanoids and lignans against Schistosoma mansoni adult worms. Planta Med., 75 (9), 945-945
Sharma, V.; Sharma, C. and Sharma, C. (2011): Influence of Curcuma longa and Curcumin on blood profile in mice subjected to aflatoxin B. international journal of pharmaceutical science and research., 2(7),1740-1745.

Sharma, R.A.; Gescher, A.J. and Steward, W.P. (2005): Curcumin: the story so far. Eur J. Cancer., 41, 1955-68.

Sturrock, R.F.; Kariuki, H.C. and Thiongo, F.W. (1996): Schistosoma mansoni in Kenya: relationship between in- fection and anemia. Trans. Roy. Soc. Trop. Med. Hyg., 90, 48-54.

Tamhane, A.C. and Dunlop, D.D. (2000): Statistic and data analysis from Elementary to Intermediate. Upper Saddle River, USA.

Torben, W. and Hailu, A. (2007): Serum cytokinese of the $20 \mathrm{Krad}$-irradiated S. mansoni cercariae vaccinated, primary and superinfected Cercopethicus aethiops aethiops. Exp. Parasitol., 115, 121-126.

Tu, C.T.; Han, B.; Liu, H.C. and Zhang, S.C. (2011): Curcumin protects mice against concanavalin A-induced hepatitis by inhibiting intrahepatic intercellular adhesion molecule-1(ICAM-1) and CXCL10 expression. Mol. Cell. Biochem., 358, 53-60.

Van der Werf, M.J.; de Vlas, S.J.; Brooker, S.; Looman, C.W.; Nagelkerke, N.J.; Habbema, J.D. and Engels, D. (2003): Quantification of clinical morbidity associated with schistosome infection in sub-Saharan Africa. Acta Trop., $86,125-139$.

Vercruysse, J.E.; Rollin, I.S. and fMaieleine, $W$. (1988): Clinical pathology of experimental Schistosoma curassoni infections in sheep and goats. Res. Vet. Sci., 44 (3), 273-281.

Warnik, G.R.; Benderson, V. and Albern, N. (1983): estimation of HDL cholesterol and selected methods Clin. Chem., 1, 91-99.

Wahlefeld, A.W. and Bergmeye, H.W. (1974): Triglycereides determination after hydrolysis in methods of enzymatic analysis Berlachmie Zeinheim and academic press inc., NewYourk and London., 1831-1835.

Willingham, A.L.; Hurst, M.; Bogh, H.O.; Johansen, M.V.; Lindberg, R.; Christensen, N.O. and Nansen, P. (1998): "Schistosom Japonicum in the pig: The hostparasite relationship as influenced by the intensity and duration of the experiment of infection. Am. J. Trop. Med. Hyg., 58(2); 248-250.

Zhang, S. and Coultas, K.A. (2013): International Journal for Parasitology: Drugs and Drug Resistance. International Journal for Parasitology: Drugs and Drug Resistance., 3, 28-34. 


\section{تأثير الكركم على صورة الام، والكيمياء الحيوية في الفئران المصابة بالبلهارسيا المعوية \\ عصام عبله محمود ، اشرف /حمد البسومي \\ E-mail: essammahmoud97@yahoo.com}

هدفت هذه الدراسة إلى دراسة تأثير الكركم على علاج البلاهارسيا في الفئران المصابة بالبلهارسيا. واستخدم في هذه التجربة التهبة

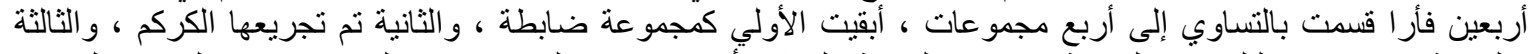

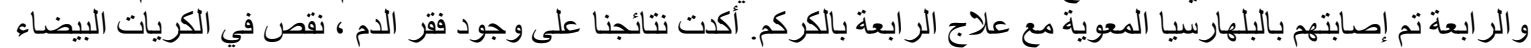

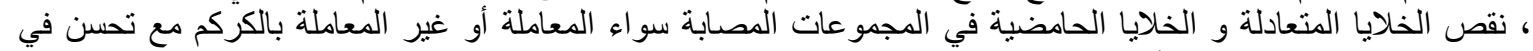

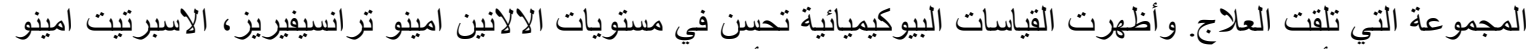

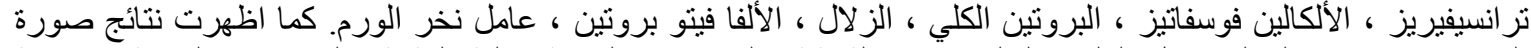

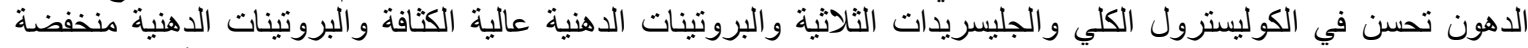

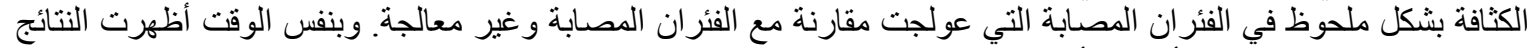

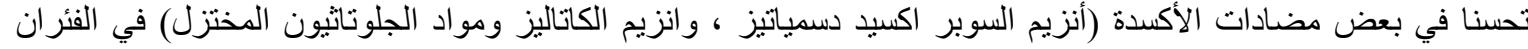

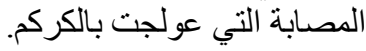

